\title{
Lichen Metabolites Modulate Hydrogen Peroxide and Nitric Oxide in Mouse Macrophages
}

\author{
Iracilda Z. Carlos ${ }^{\mathrm{a}, *}$, Marcela B. Quilles ${ }^{\mathrm{a}}$, Camila B. A. Carli ${ }^{\mathrm{a}}$, \\ Danielle C. G. Maia ${ }^{a}$, Fernanda P. Benzatti ${ }^{\mathrm{a}}$, Thiago I. B. Lopes ${ }^{\mathrm{b}}$, \\ Aline S. Gianini ${ }^{\mathrm{b}}$, Rosenei L. Brum ${ }^{\mathrm{b}}$, Wagner Vilegas ${ }^{\mathrm{c}}$, \\ Lourdes C. dos Santos ${ }^{c}$, and Neli K. Honda ${ }^{\mathrm{b}}$ \\ a UNESP - São Paulo State University, Faculdade de Ciências Farmacêuticas, \\ C. Postal 502,14801 - 902, Araraquara, SP, Brazil. Fax: 551633016559. \\ E-mail: carlosiz@fcfar.unesp.br \\ b UFMS - Mato Grosso do Sul Federal University, Departamento de Química \\ de Campo Grande, Mato Grosso do Sul, Brazil \\ c UNESP - São Paulo State University, Instituto de Química de Araraquara, \\ C. Postal 355, 14801 - 970, Araraquara, SP, Brazil \\ * Author for correspondence and reprint requests \\ Z. Naturforsch. 64c, 664-672 (2009); received March 9/May 8, 2009
}

The activities of perlatolic acid (1), atranorin (2), and lecanoric acid (3) and their derivatives, such as orsellinates and $\beta$-methyl orsellinates obtained by alcoholysis, were assessed for stimulation of the release of hydrogen peroxide and nitric oxide in cultures of peritoneal macrophage cells from mice. The hydrogen peroxide production was estimated by oxidation of phenol red, while the Griess reagent was used to determine the nitric oxide production. 1 and 4-methoxy-ethyl orsellinate (XVII) were the compounds that induced the greatest release of $\mathrm{H}_{2} \mathrm{O}_{2}$, whereas $n$-pentyl orsellinate (IV), iso-propyl orsellinate (V), sec-butyl orsellinate (VI), and XVII induced a small release of NO. These results indicate that lichen products and their derivatives have potential immune-modulating activities.

Key words: Lichens, Hydrogen Peroxide, Nitric Oxide

\section{Introduction}

Lichens are symbiotic associations of a fungus, which forms the main structure of the organism (thallus), with the photosynthetic cells of a green alga and/or cyanobacterium (González et al., 2005). They are slow-growing organisms and their secondary metabolites are mainly depsides, depsidones, dibenzofurans, xanthones, anthraquinones and terpene derivatives (Müller, 2001).

Lichen-forming fungi are unique organisms, producing biologically active metabolites with a great variety of effects, including antibiotic, antimycobacterial, antiviral, anti-inflammatory, analgesic, antipyretic, antiproliferative and cytotoxic activities (Boustie and Grube, 2005; Carli et al., 2009). However, only very limited numbers of lichen substances have been screened for their biological activities and their therapeutic potential in medicine.

Macrophages are the first cells to participate in the immunological response and they can be activated by a variety of stimuli such as bacterial components, cytokines and chemicals. Their principal functions include the phagocytosis of foreign particles, presentation of antigens to other cells, production of cytokines and the release of reactive oxygen species (ROS) and reactive nitrogen intermediates (RNI) during the "oxidative burst" (Pick and Keisari, 1980; Pick and Mizel, 1981).

Hydrogen peroxide $\left(\mathrm{H}_{2} \mathrm{O}_{2}\right)$ plays an important role in the functions of macrophages (Puri et al., 1994; Ramasarma, 1990). The products of the oxidative burst are used to kill phagocytosed pathogens and for the extracellular destruction of other cells. In addition to $\mathrm{H}_{2} \mathrm{O}_{2}$ and $\mathrm{O}_{2}^{-}$, two other highly reactive oxygen species have been implicated in the killing process, viz. hydroxyl radicals $(\mathrm{OH})$ and singlet oxygen. This coordinated sequence of biochemical reactions is initiated by an increase in oxygen uptake followed by the oneelectron reduction of oxygen to the superoxide anion $\left(\mathrm{O}_{2}^{-}\right)$, with NADPH or NADH as the electron donor, catalyzed by an $\mathrm{NAD}(\mathrm{P}) \mathrm{H}$ oxidase. $\mathrm{O}_{2}^{-}$is subsequently converted to $\mathrm{H}_{2} \mathrm{O}_{2}$ (Pick and Mizel, 1981). 
Nitric oxide (NO) is involved in many physiological processes in mammals, including neurotransmission, blood pressure control, inflammation, immune responses and also in the mechanism of defense against invasive organisms and tumours (Costa et al., 2003). It is identified as the major effector molecule in the destruction of tumour cells by activated macrophages. The involvement of NO during nonspecific host defense, macrophage-mediated killing or inhibition (in vitro and in vivo) of the proliferation of microorganisms and tumour cells has been demonstrated in previous research. Furthermore, several studies have shown that activated macrophages produce NO, and RNI are believed to play a significant role in tumouricidal and microbicidal activities (Chul et al., 2001). Peroxynitrite $\left(\mathrm{ONOO}^{-}\right)$is produced by spontaneous combination of $\mathrm{NO}$ and $\mathrm{O}_{2}^{-}$, released, for example, during reperfusion (Ferdinandy, 2006). Of all the ROS and RNI generated during oxidative stress, peroxynitrite is one of the most reactive and toxic ones (Beckman and Koppenol, 1996). In sum, RNI and ROS represent important mediators of the microbicidal and antitumoural activity of macrophages, contributing to the nonspecific response of the host and the inflammatory process (Xie and Fidler, 1998).

As a continuation of our work aimed to discover phenolic compounds isolated from lichens and their cytotoxic effects on cultured macrophages (Santos et al., 2004), the focus of the present study was to determine in vitro the cytotoxicity to mouse peritoneal macrophages of perlatolic acid (1), atranorin (2), and lecanoric acid (3) and their derivatives, obtained by alcoholysis, and to investigate the liberation of $\mathrm{H}_{2} \mathrm{O}_{2}$ and $\mathrm{NO}$ by these cells in their presence.

\section{Experimental}

\section{Lichens}

The lichen Parmotrema tinctorum (Nyl.) Hale was collected in the Brazilian state of Mato Grosso do Sul in July 2005; Cladina confusa (Sant.). Folmm \& Ahti was obtained from a shop of decoration products. Specimens were identified by Dr. Mariana Fleig, Botany Department, Universidade Federal do Rio Grande do Sul (UFRGS), Brazil, and Dr. Marcelo P. Marcelli, São Paulo Institute of Botany, Brazil. A voucher specimen of each species was deposited in our laboratory for future reference.

\section{Extraction and isolation of compounds}

The dried lichen $C$. confusa $(240.0 \mathrm{~g})$ was extracted with hexane $(4 \times 0.6 \mathrm{~L})$ and then with acetone $(3 \times 0.6 \mathrm{~L})$ at room temperature, and. $P$. tinctorum $(300.0 \mathrm{~g})$ with chloroform $(3 \times 0.7 \mathrm{~L})$, followed by acetone $(3 \times 0.7 \mathrm{~L})$, at $45^{\circ} \mathrm{C}$ in a water bath. The extracts were concentrated in vacuo. The concentrated hexane extract from $C$. confusa $(2.5 \mathrm{~g})$ and the chloroform extract from P. tinctorum $(0.5 \mathrm{~g})$ were fractionated on a silica-gel chromatography column and eluted with a hexane/acetone gradient of rising polarity, to give perlatolic acid (1) (C. confusa) and atranorin (2) (P. tinctorum). The concentrated acetone extract of $P$. tinctorum was treated by the method described by Ahmann and Mathey (1967), in which lecanoric acid (3) was finally precipitated from an aqueous alkaline solution by acidification. The degree of purity of all the lichen compounds isolated was higher than $95 \%$, as determined by TLC and NMR analyses. In the immunological assays the compounds were diluted in 4\% DMSO (dimethylsulfoxide) and the lichen materials were used as soon as they were obtained.

\section{Derivatives}

The alcoholysis of lecanoric (3) and perlatolic (1) acids and purification of the products were conducted as described by Gomes et al. (2006) and Gianini et al. (2008). The 2,4-dihydroxy-6methylbenzoates I-VII (orsellinates) and 2-hydroxy-4-methoxy-6- $n$-pentylbenzoates VIII-XV were obtained from $\mathbf{3}$ and $\mathbf{1}$, respectively.

Methyl- $\beta$-methyl orsellinate (XVI) was obtained by alcoholysis of $\mathbf{2}$ with methanol. The mixture was fractionated on a silica-gel column with a mobile phase of chloroform/toluene 1:1 $(\mathrm{v} / \mathrm{v})$.

4-Methoxy-ethyl orsellinate (XVII) was obtained by methylation of ethyl orsellinate, as described by Elix et al. (1990). It was separated on a flash silica-gel column with hexane/ethyl acetate 70:30 (v/v).

The structures were confirmed by NMR spectroscopy $\left({ }^{1} \mathrm{H}\right.$ and ${ }^{13} \mathrm{C}$ ) (Huneck and Yoshimura, 1996). 2D NMR spectra (HMBC and HMQC) were also recorded.

In the immunological assays the derivatives were diluted in 4\% DMSO and the lichen derivatives were used as soon as they were obtained. 


\section{Animals}

Swiss mice (6-8 weeks old, weighting 18$25 \mathrm{~g}$ ) were maintained in a polycarbonate box at $(23 \pm 1){ }^{\circ} \mathrm{C},(55 \pm 5) \%$ humidity, 10-18 circulations/h and a $12 \mathrm{~h}$ light/dark cycle, with water and food available ad libitum. At least five animals were used for each experiment. All animals were maintained and handled according to International Ethical Guidelines for the Care of Laboratory Animals (Faculty Ethics Committee \# 06/2005).

\section{Peritoneal exudate cells}

Thioglycolate-elicited peritoneal exudate cells (PECs) were harvested from Swiss mice in $5.0 \mathrm{~mL}$ of sterile phosphate-buffered saline (PBS), pH 7.4. The cells were washed three times by centrifugation at $200 \times g$ for $5 \mathrm{~min}$ at $4{ }^{\circ} \mathrm{C}$ with $3.0 \mathrm{~mL}$ PBS. The cells were then resuspended in $1.0 \mathrm{~mL}$ RPMI-1640 culture medium (Sigma) containing $2 \cdot 10^{-5}$ м $\beta$-mercaptoethanol (Sigma), 100 $\mathrm{U} / \mathrm{mL}$ penicillin (Sigma), $100 \mathrm{U} / \mathrm{mL}$ streptomycin (Sigma), 2 mm L-glutamine (Sigma), and 5\% fetal bovine serum (Sigma). This medium was denoted complete RPMI-1640 (RPMI-1640-C) medium and was used for cell counts in a Neubauer chamber (Boeco, Germany). For the proposed tests, the cell suspension was adjusted to a concentration of $5 \cdot 10^{6}$ cells.

\section{MTT assay for cell viability}

PECs $\left(5 \cdot 10^{6}\right.$ cells $\left./ \mathrm{mL}\right)$ were resuspended in RPMI-1640 culture medium containing 5\% heatinactivated fetal bovine serum (FBS), $100 \mathrm{IU} / \mathrm{mL}$ penicillin, $100 \mu \mathrm{g} / \mathrm{mL}$ streptomycin and $50 \mathrm{~mm}$ 2 -mercaptoethanol. The suspension $(100 \mu \mathrm{L})$ and the test material $(100 \mu \mathrm{L})$ were added to each well of a 96-well tissue culture plate, and the plates were incubated for $24 \mathrm{~h}$. The 3-(4,5-dimethylthiazol-2-yl)-2,5-diphenyl-tetrazolium bromide (MTT) assay was performed and the absorbance at $540 \mathrm{~nm}$ determined with an ELISA microplate reader (Multiskan Ascent Labsystems, Helsinki, Finland). Cells and culture medium (RPMI-1640) alone were used as a control representing 100\% macrophage viability (Mosmann, 1983).

\section{$\mathrm{H}_{2} \mathrm{O}_{2}$ measurement}

PECs $\left(2 \cdot 10^{6}\right.$ cells $\left./ \mathrm{mL}\right)$ were cultivated as described above and suspended in a solution con- taining $140 \mathrm{mmol} \mathrm{NaCl}, 10 \mathrm{mmol}$ potassium phosphate buffer, $\mathrm{pH} 7.0,5.5 \mathrm{mmol}$ dextrose, $0.56 \mathrm{mmol}$ phenol red, and $0.01 \mathrm{mg} / \mathrm{mL}$ type II horseradish peroxidase, called complete buffer. Next, $100 \mu \mathrm{L}$ of this suspension were added to each of the wells of a 96-well flat-bottom tissue culture plate and exposed to $50 \mu \mathrm{L}$ of each compound. Phorbol 12-myristate 13-acetate (PMA) solution in phosphate buffer was used as a positive control and complete buffer alone as a negative control. The cells were incubated for $1 \mathrm{~h}$ at $37{ }^{\circ} \mathrm{C}$ in a mixture of $95 \%$ air and $5 \% \mathrm{CO}_{2}$. The reaction was stopped with $10 \mu \mathrm{L}$ of $4 \mathrm{M} \mathrm{NaOH}$ and the absorption of the samples was read at $620 \mathrm{~nm}$ in an ELISA microplate reader (Multiskan Ascent Labsystems) against a blank containing phenol red solution and $4 \mathrm{~m} \mathrm{NaOH}$. The results, expressed in nmol of $\mathrm{H}_{2} \mathrm{O}_{2}$ per $2 \cdot 10^{5}$ PECs, were read from a standard curve established in each test with known molar concentrations of $\mathrm{H}_{2} \mathrm{O}_{2}$ in complete buffer. At least four experiments were used for the test (Pick and Keisari, 1980; Pick and Mizel, 1981).

\section{NO measurement}

PECs $\left(5 \cdot 10^{6}\right.$ cells $\left./ \mathrm{mL}\right)$ were resuspended in RPMI-1640-C culture medium, and $100 \mu \mathrm{L}$ of this suspension were added to each well of a 96well tissue culture plate, together with various derivatives obtained from lichens. Escherichia coli O26:B6 lipopolysaccharide (LPS) was used as a positive control and RPMI-1640 medium alone as a negative control. After incubation for $24 \mathrm{~h}$ at $37^{\circ} \mathrm{C}$ in humid atmosphere, $50-\mu \mathrm{L}$ aliquots of culture supernatant were mixed with $50 \mu \mathrm{L}$ of Griess reagent $(1 \% \mathrm{w} / \mathrm{v}$ sulfanylamide, $0.1 \% \mathrm{w} / \mathrm{v}$ naphthylethylenediamine, and $\left.3 \% \mathrm{H}_{3} \mathrm{PO}_{4}\right)$, incubated at room temperature for $10 \mathrm{~min}$ and the colour reaction was determined at $540 \mathrm{~nm}$ in an ELISA microplate reader (Multiskan Ascent Labsystems). Supernatants from quadruplicate cultures were assayed in four experiments and reported as $\mu$ mol NO per $5 \cdot 10^{5}$ cells, calibrated against solutions of known $\mathrm{NaNO}_{2}$ concentration (Green et al., 1982).

\section{Statistical analysis}

Data are expressed as mean \pm standard deviation (SD), and Dunn's $t$-test (Microcal Origin 5.0) was used to determine the significance of the differences between the control and experimental compounds. 


\section{Results and Discussion}

Perlatolic acid (1) was isolated from C. confusa and atranorin (2) and lecanoric acid (3) from $P$. tinctorum. The derivatives I-XVII were obtained by alcoholysis of $\mathbf{1}, \mathbf{2}$ and $\mathbf{3}$ (Fig. 1).

To examine the cytotoxic effects, the viability of PECs was measured by the MTT assay after their treatment with the compounds at various concentrations (Table I). The data presented in this table show the concentration used in the subsequent tests, at which the viability was $50 \%$ of the cells or higher (Fig. 2).

In the MTT assay, the yellow tetrazolium salt MTT is taken up into cells and reduced by a mitochondrial dehydrogenase to yield a purple for- mazan that is largely impermeable to cell membranes, thus resulting in its accumulation within healthy cells. The ability of cells to reduce MTT provides an indication of the mitochondrial integrity and activity which, in turn, may be interpreted as a measure of viability and/or cell number (Mosmann, 1983).

RNI and ROS represent important mediators of the microbicidal and antitumoural activity of the macrophages and contribute to the nonspecific immune response of the host and the inflammatory process (Xie and Fidler, 1998; Carlos et al., 2003; Carli et al., 2009). The macrophages act as a first line of defense of the host and release a great number of factors, including $\mathrm{NO}$ and $\mathrm{H}_{2} \mathrm{O}_{2}$,

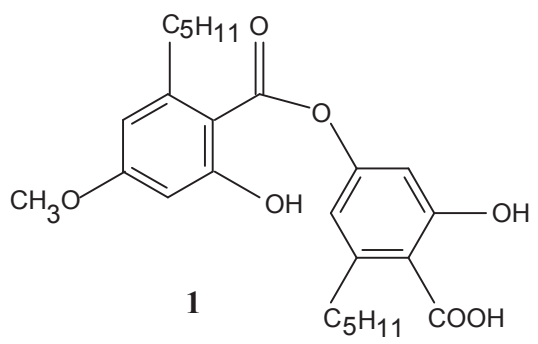<smiles>CC(=O)c1c(C)cc(OC(=O)c2c(C)cc(O)c(C=O)c2O)c(C)c1O</smiles><smiles>Cc1cc(OC(=O)c2c(C)cc(O)cc2O)cc(O)c1C(=O)O</smiles><smiles>CC(=O)c1c(C)cc(O)c(C)c1O</smiles><smiles>CCOC(=O)c1c(C)cc(OC)cc1O</smiles>

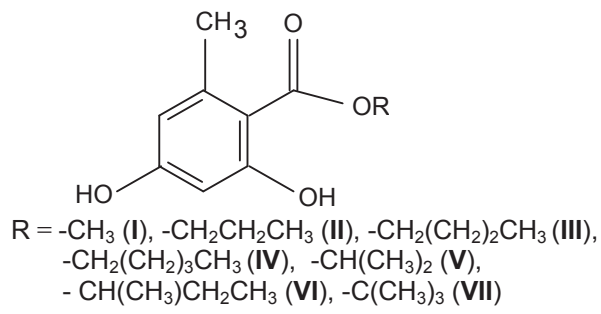

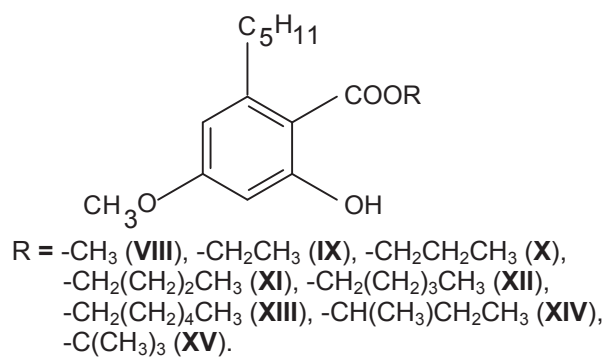

Fig. 1. Chemical structures of the compounds assayed for viability of peritoneal macrophages. 
Table I. Compounds and their concentration used in the tests.

\begin{tabular}{lc}
\hline Compound & $\begin{array}{c}\text { Test concentration } \\
{[\mathrm{mg} / \mathrm{mL}]}\end{array}$ \\
\hline Perlatolic acid (1) & 0.031 \\
Methyl orsellinate (I) & 0.25 \\
$n$-Propyl orsellinate (II) & 0.0625 \\
$n$-Butyl orsellinate (III) & 0.031 \\
$n$-Pentyl orsellinate (IV) & 0.031 \\
iso-Propyl orsellinate (V) & 0.0625 \\
sec-Butyl orsellinate (VI) & 0.031 \\
tert-Butyl orsellinate (VII) & 0.031 \\
Methyl-2-hydroxy-4-methoxy-6- $n$-pentylbenzoate (VIII) & 0.0625 \\
Ethyl-2-hydroxy-4-methoxy-6- $n$-pentylbenzoate (IX) & 0.125 \\
$n$-Propyl-2-hydroxy-4-methoxy-6- $n$-pentylbenzoate (X) & 0.0156 \\
$n$-Butyl-2-hydroxy-4-methoxy-6- $n$-pentylbenzoate (XI) & 0.0625 \\
$n$-Pentyl-2-hydroxy-4-methoxy-6- $n$-pentylbenzoate (XII) & 0.031 \\
$n$-Hexyl-2-hydroxy-4-methoxy-6- $n$-pentylbenzoate (XIII) & 0.031 \\
sec-Butyl-2-hydroxy-4-methoxy-6- $n$-pentylbenzoate (XIV) & 0.031 \\
tert-Butyl-2-hydroxy-4-methoxy-6- $n$-pentylbenzoate (XV) & 0.25 \\
Methyl- $\beta$-methyl orsellinate (XVI) & 0.0625 \\
4-Methoxy-ethyl orsellinate (XVII) & 0.5 \\
\hline
\end{tabular}

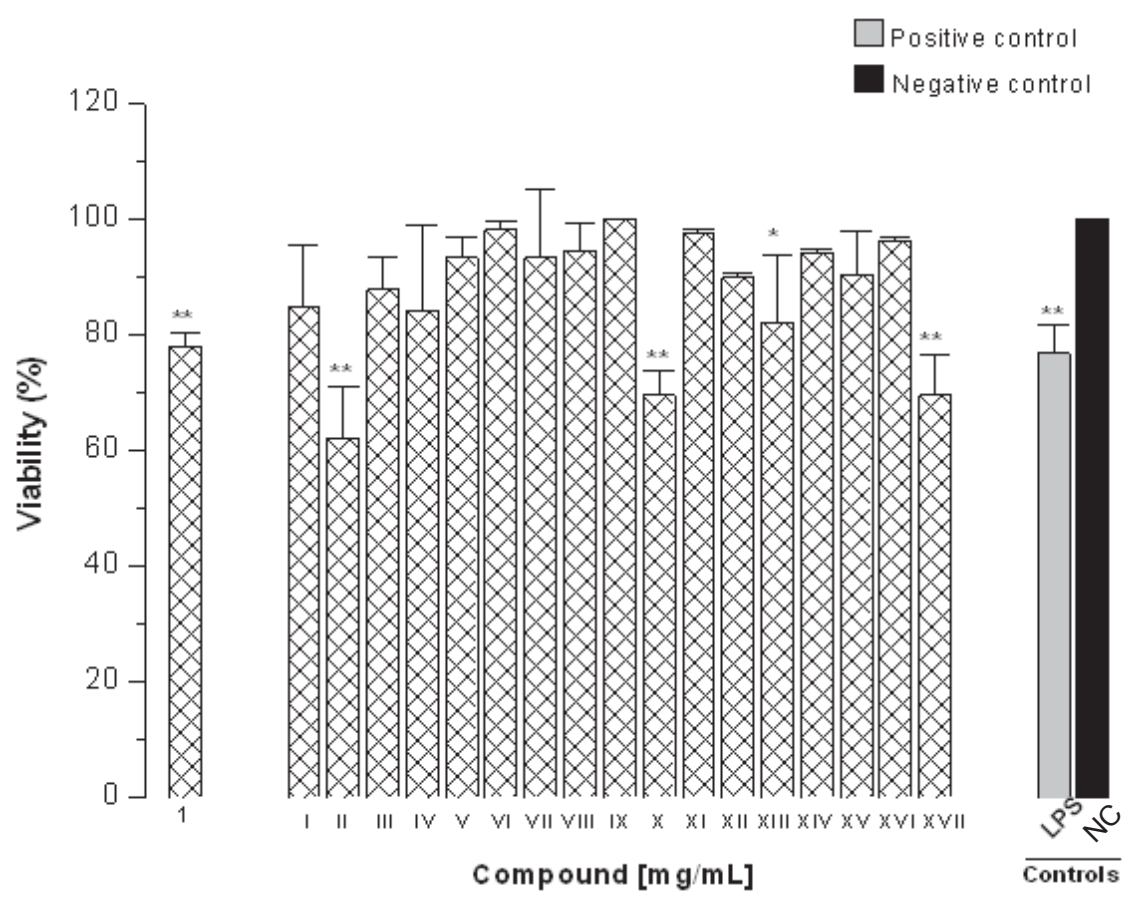

Fig. 2. Viability of peritoneal macrophages activated by compounds isolated from the lichens. PECs $\left(5 \cdot 10^{6}\right.$ cells/ $\mathrm{mL})$ were resuspended in RPMI-1640-C medium and the suspension (100 $\mu \mathrm{L})$ was incubated with the test compounds $(100 \mu \mathrm{L})$ for $24 \mathrm{~h}$. LPS solution was the positive control and the medium (RPMI-1640) alone was the negative control (NC, $100 \%$ viability). MTT solution was added $(100 \mu \mathrm{L})$ to the cells and the plate was incubated for $3 \mathrm{~h}$. Each bar represents the mean \pm SD of five experiments. $* p<0.5$ and $* * p<0.01$, significantly different from the negative control. 
powerful mediators of the immune and inflammatory responses (Laskin and Pendino, 1995).

$\mathrm{H}_{2} \mathrm{O}_{2}$ plays a variety of roles in the body, for example as signaling molecule, intermediate in metabolism, cytotoxic agent in host defense and cytotoxic agent in pathology (Halliwell et al., 2000; Samali et al., 1999). $\mathrm{H}_{2} \mathrm{O}_{2}$ has important functions in the intracellular and intercellular reactions of various cells. Under normal physiological conditions, it is generated in small quantities and is rapidly used or degraded, but longer exposures to high concentrations of this molecule can destroy biological structures and lead to irreversible cell damage. $\mathrm{H}_{2} \mathrm{O}_{2}$ is toxic to cells and is indeed responsible for killing internalized bacteria in phagocytosis (Ramasarma, 1990).

The release of $\mathrm{H}_{2} \mathrm{O}_{2}$ was measured as the amount of substance (in nmol) produced by $2 \cdot 10^{5}$ cells after $1 \mathrm{~h}$ of incubation with the compounds. Among the tested compounds, perlatolic acid (1) stimulated the release of $(10.48 \pm 0.96) \mathrm{nmol}$ $\mathrm{H}_{2} \mathrm{O}_{2}$, and 4-methoxy-ethyl orsellinate (XVII) led to the release of $(13.34 \pm 1.17) \mathrm{nmol} \mathrm{H}_{2} \mathrm{O}_{2}$. It was observed that the compounds $n$-pentyl orsellinate
(IV), tert-butyl orsellinate (VII) and methyl- $\beta$ methyl orsellinate (XVI) stimulated a more modest release of this mediator, while PMA (positive control), a powerful immunostimulator, was able to release $(26.73 \pm 1.23) \mathrm{nmol} \mathrm{H}_{2} \mathrm{O}_{2}$. The quantity of $\mathrm{H}_{2} \mathrm{O}_{2}$ released in response to compounds VIII$\mathbf{X V}$, synthesized by alcoholysis of perlatolic acid (1), was very low, though even a small amount more than the negative control is an important result (see Fig. 3), as it may modulate the immune response without causing cytotoxicity. The relationships between the chemical structures of the orsellinates IV, VII and XVI obtained by alcoholysis of lecanoric acid (3) are shown in Fig. 1. The aromatic ring of IV and VII bears hydroxy groups at positions 2 and 4 and a methyl group at position 6 . The difference among them lies in the ester chain. Results show that chain elongation of the series of 2,4-dihydroxy-6-n-methyl benzoates (methyl to pentyl orsellinates, II-IV) and compounds with branched chains (iso-propyl, sec-butyl and tert-butyl orsellinates, V-VII) lead to higher lipophilicity and induce a greater release of $\mathrm{H}_{2} \mathrm{O}_{2}$. However, compounds VIII to

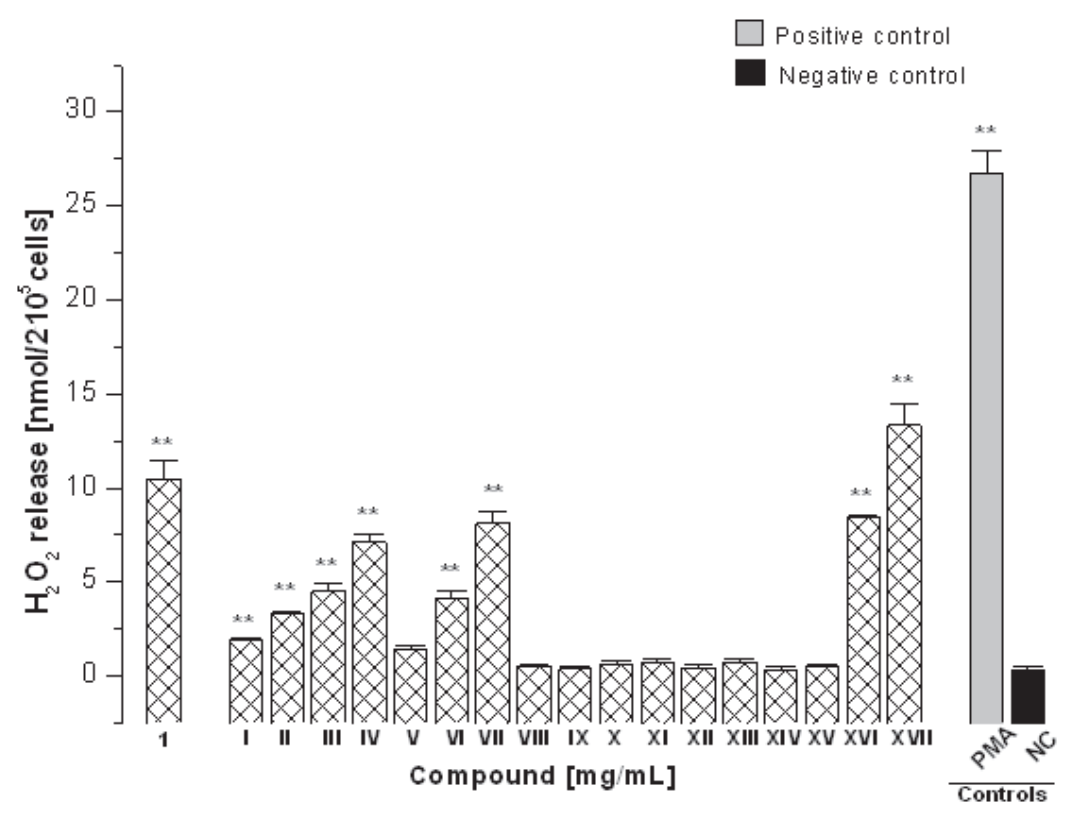

Fig. 3. Hydrogen peroxide production by PECs in the presence of compounds isolated from the lichens. Adherent cells $\left(100 \mu \mathrm{L}\right.$ PECs suspended at $2 \cdot 10^{6}$ cells $\left./ \mathrm{mL}\right)$ were incubated for $1 \mathrm{~h}$ with $50 \mu \mathrm{L}$ of test solution. PMA was the positive control and the medium (RPMI-1640) alone was the negative control (NC). The reaction was stopped with $10 \mu \mathrm{L}$ of $4 \mathrm{M} \mathrm{NaOH}$. Each bar represents the mean \pm SD of five experiments. ** $p<0.01$, significantly different from the negative control. 
$\mathbf{X V}$, obtained by alcoholysis of perlatolic acid (1), were weakly active. These compounds differ from orsellinates in having a methoxy group at C-4 and an $n$-pentyl chain at C-6. Thus, the esters of 2-hydroxy-4-methoxy-6- $n$-pentylbenzoates are more lipophilic than the orsellinates and the lower activity may be related to the $n$-pentyl group at C-6 in the aromatic ring of these compounds. The good activity shown by methyl- $\beta$-methyl orsellinate (XVI) suggests that the methyl group at C-3 also causes an increase in the release of $\mathrm{H}_{2} \mathrm{O}_{2}$. The greatest activity was shown by 4-methoxy-ethyl orsellinate (XVII) and this may be explained by the lower polarity of this compound. These results suggest that the activity of these compounds depend on an equilibrium between the hydrophilic and lipophilic properties.

Reactive oxygen metabolites (like $\mathrm{H}_{2} \mathrm{O}_{2}$ ) have been suggested as potentially important signaling molecules in both intra- and intercellular reactions in a number of different cell types. It has been well documented that reactive species such as $\mathrm{H}_{2} \mathrm{O}_{2}$ are produced by activated inflammatory cells (Rochele et al., 1998).
NO produced by activated macrophages plays a role in both inflammatory and anti-inflammatory processes. It is involved in the killing or inhibition of the proliferation of microorganisms, destruction of tumour cells by activated macrophages, and nonspecific host defense (Stuehr and Nathan, 1989; Hibbs et al., 1987). At the site of an acute inflammatory reaction, all the conditions are met for the generation of $\mathrm{NO}$ and for a role of this compound as an inflammatory mediator (Moncada, 1999). NO is a messenger molecule involved in the regulation of diverse physiological processes and the cytotoxic actions of immunological cells. When found in high concentrations, this mediator can become involved in numerous pathological processes (Hibbs et al., 1987; Maia et al., 2006).

The compounds $n$-pentyl orsellinate (IV), isopropyl orsellinate (V), sec-butyl orsellinate (VI) and 4-methoxy-ethyl orsellinate (XVII) stimulated a small release of NO (Fig. 4) compared to the positive control LPS. However, the quantities are significant, showing that these compounds are able to stimulate the immune system without

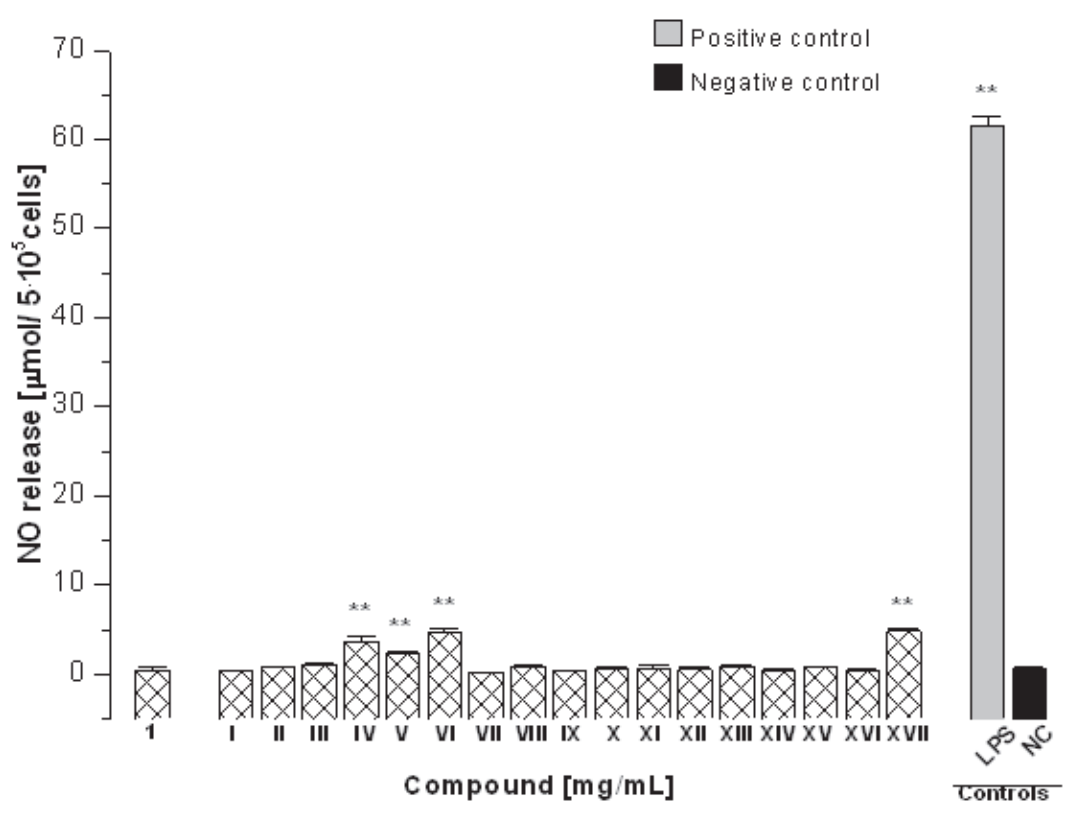

Fig. 4. Nitric oxide production by PECs in the presence of compounds isolated from the lichens. Adherent cells $\left(100 \mu \mathrm{L}\right.$ PECs suspended at $5 \cdot 10^{6}$ cells $\left./ \mathrm{mL}\right)$ were incubated for $24 \mathrm{~h}$ with $100 \mu \mathrm{L}$ of test solution. Cell-free supernatant was drawn off and mixed with Griess reagent. LPS was the positive control and the medium (RPMI-1640) alone was the negative control (NC). Each bar represents the mean $\pm \mathrm{SD}$ of five experiments. ** $p<0.01$, significantly different from the negative control. 
causing cell damage due to the cytotoxic effect of NO at high concentrations (Park, 2006).

The methyl (I), $n$-propyl (II), $n$-butyl (III) and $n$-pentyl orsellinates (IV) showed an increasing release of NO with increasing lipophilicity, although the amount of NO produced was little compared to the positive control. The esters of 2-hydroxy-4-methoxy-6- $n$-pentylbenzoates VIII$\mathbf{X V}$ and methyl- $\beta$-methyl orsellinate (XVI) were less active, all of them showing practically the same activity.

In conclusion, the best activities for the $\mathrm{H}_{2} \mathrm{O}_{2}$ release were observed with compounds IV, VII, XVI and XVII, while for NO release the best ac-

Ahmann G. B. and Mathey A. (1967), Lecanoric acid and some constituents of Parmelia tinctorum and Pseudevernia intensa. Bryologist 70, 93-97.

Beckman J. S. and Koppenol W. H. (1996), Nitric oxide, superoxide, and peroxynitrite: the good, the bad, and ugly. Am. J. Physiol. 271, 1424-1437.

Boustie J. and Grube M. (2005), Lichens - a promising source of bioactive secondary metabolites. Plant Genet. Res. 3, 273-287.

Carli C. B. A., Matos D. C., Lopes F. C. M., Maia D. C. G, Dias M. B., Sannomiya M., Rodrigues C. M., Andreo M. A., Vilegas W., Colombo L. L., and Carlos I. Z. (2009), Isolated flavonoids against mammary tumour cells LM2. Z. Naturforsch. 64c, 32-36.

Carlos I. Z., Sgarbi D. B. G., Santos G. C., and Placeres M. C. P. (2003), Sporothrix schenckii lipid inhibits the macrophage phagocytosis: involvment of nitric oxide and tumour necrosis factor-alpha. Scand. J. Immunol. 57, 214-220.

Chul Y. C., Ji Y. K., Young S. K., Young C. C., Jong K. S., and Hye G. J. (2001), Aqueous extract isolated from Platycodon grandiflorum elicits the release of nitric oxide and tumor necrosis factor-alpha from murine macrophages. Int. Immunopharmacol. 1, 1141-1151.

Costa M. T., Fabeni R. C., Aptekmann K. P., and Machado R. R. (2003), Diferentes papéis do óxido nítrico com ênfase nas neoplasias. Ciência Rural. 33, 967-974.

Elix J. A., Jiang H., and Wardlaw J. H. (1990), A new synthesis of xanthones: 2,4,7-trichloronorlichexanthone and 4,5,7-trichloronorlichexanthone, two new lichen xanthones. Aust. J. Chem. 43, 1745-1758.

Ferdinandy P. (2006), Peroxynitrite: just an oxidative/ nitrosative stressor or a physiological regulator as well? Br. J. Pharmacol. 148, 1-3.

Gianini A. S., Marques M. R., Carvalho N. C. P., and Honda N. K. (2008), Activities of 2,4-dihyroxy-6- $n$ pentylbenzoic acid derivatives. Z. Naturforsch. 63c, 29-34.

Gomes A. T., Honda N. K., Roese F. M., Muzzi R. M., and Sauer L. (2006), Cytotoxic activity of orsellinates. Z. Naturforsch. 61c, 653-657. tivities were observed with compounds IV, V, VI and XVII, in comparison with PMA and LPS as positive controls. These results indicate that certain compounds isolated from lichens and their derivatives have potential immune-modulating activities.

\section{Acknowledgements}

We are indebted to Dr. Marcelo P. Marcelli (Instituto de Botânica de São Paulo) and Dr. Mariana Fleig for the lichen identification, and to FUNDECT for financial support. A. S. Gianini thanks FUNDECT and T. I. B. Lopes thanks the PET program for their fellowships.

González I., Ayuso-Sacido A., Anderson A., and Genilloud O. (2005), Actinomycetes isolated from lichens: Evaluation of their diversity and detection of biosynthetic gene sequence. FEMS Microbiol. Ecol. 54, $401-415$.

Green L. C., Wagner D. A., Glogowski J., Skipper P. L., Wishnok J. S., and Tannenbaum S. R. (1982), Analysis of nitrate, nitrite, and $\left[{ }^{15} \mathrm{~N}\right]$ nitrate in biological fluids. Anal. Biochem. 126, 131-138.

Halliwell B., Clement M. V., and Long L. H. (2000), Hydrogen peroxide in the human body. FEBS Lett. 486, $10-13$.

Hibbs J. B., Taintor R. R., and Vavrin Z. (1987), Macrophage cytotoxicity: role for L-arginine deiminase and imino nitrogen oxidation to nitrite. Science $\mathbf{2 3 5}$, $473-476$.

Huneck S. and Yoshimura I. (1996), Identification of Lichen Substances. Springer, Berlin.

Laskin D. L. and Pendino K. J. (1995), Macrophages and inflammatory mediators in tissue injury. Annu. Rev. Pharmacol. Toxicol. 35, 655-677.

Maia D. C. G., Sassa M. F., Placeres M. C. P., and Carlos I. Z. (2006), Influence of Th1/Th2 cytokines and nitric oxide in murine systemic infection induced by Sporothrix schenckii. Mycopathology 161, 11-19.

Moncada S. (1999), Nitric oxide: discovery and impact on clinical medicine. J. R. Soc. Med. 92, 164-169.

Mosmann T. (1983), Rapid colorimetric assay for cellular growth and survival: Application and cytotoxicity assays. J. Immunol. Methods 65, 55-63.

Müller K. (2001), Pharmaceutically relevant metabolites from lichens. Appl. Microbiol. Biotechnol. 56, 9-16.

Park H. (2006), The pathophysiology of irritable bowel syndrome: inflammation and motor disorder. Korean J. Gastroenterol. 47, 101-110.

Pick E. and Keisari Y. (1980), A simple colorimetric method for the measurement of hydrogen peroxide produced by cells in culture. J. Immunol. Methods 38 , 161-170.

Pick E. and Mizel D. J. (1981), Rapid microassays for the measurement of superoxide and hydrogen peroxide production by macrophages in culture using an 
automatic enzyme immunoassay reader. J. Immunol. Methods 46, 211-226.

Puri A., Saxena R. P., and Saxena K. C. (1994), Immunostimulant agents from Andrographis paniculata. J. Nat. Prod. 56, 995-999.

Ramasarma T. (1990), $\mathrm{H}_{2} \mathrm{O}_{2}$ has a role in cellular regulation. Indian J. Biochem. Biophys. 27, 269-274.

Rochele L. G., Fischer B. M., and Adler K. B. (1998), Concurrent production of reactive oxygen and nitrogen species by airway epithelial cells in vitro. Free. Rad. Biol. Med. 24, 863-868.

Samali A., Nordgren H., Zhivotovsky B., Peterson E., and Orrenius S. (1999), A comparative study of apoptosis and necrosis in HepG2 cells: oxidant-induced caspase inactivation leads to necrosis. Biochem. Biophys. Res. Commun. 255, 6-11.

Santos L. C., Honda N. K., Carlos I. Z., and Vilegas W. (2004), Intermediate reactive oxygen and nitrogen from macrophages induced by Brazilian lichens. Fitoterapia $\mathbf{7 5}, 473-479$.

Stuehr D. J. and Nathan C. F. (1989), Nitric oxide. A macrophage product responsible for cytostasis and respiratory inhibition in tumor target cells. J. Exp. Med. 169, 1543-1555.

Xie K. and Fidler I. J. (1998), Therapy of cancer metastasis by activation of the inducible nitric oxide synthase. Cancer Metastasis Rev. 17, 55-75. 